\title{
Unusual extracranial spread of glioblastoma
}

\author{
Ricardo J Fernández-de Thomas (1) , Joel E Pellot Cestero, Cesar M Carballo Cuello, \\ Orlando De Jesus
}

Department of Surgery, Neurosurgery Section, University of Puerto Rico Medical Sciences Campus, San Juan, Puerto Rico

\section{Correspondence to}

Dr Orlando De Jesus; drodejesus@aol.com

Accepted 5 August 2021

\section{DESCRIPTION}

We present an unusual case of glioblastoma, which spread to the left sphenoid sinus 13 months after the initial surgery. A 50-year-old man initially presented with a slight right haemiparesis $4+/ 5$ and mild right facial weakness. The brain MRI showed a large contrast-enhancing lesion centred at the left temporal lobe with a possible extension of the mass through the greater wing of the left sphenoid bone into the left sphenoid sinus (figure 1). The maxillofacial CT scan showed dehiscence of the posterior wall of the left sphenoid sinus. He underwent a left temporal craniotomy with temporal lobectomy and gross tumour resection. There were no evident macroscopic signs of invasion of the dura mater. Intraoperative inspection showed no visible defect at the temporal floor dura. The right haemiparesis improved rapidly after the surgery. Histopathological analysis confirmed the diagnosis of glioblastoma. Biomolecular studies were not performed due to insurance coverage. The patient received radiotherapy for a total of $60 \mathrm{~Gy}$ plus continuous daily temozolomide, followed by 10 monthly cycles

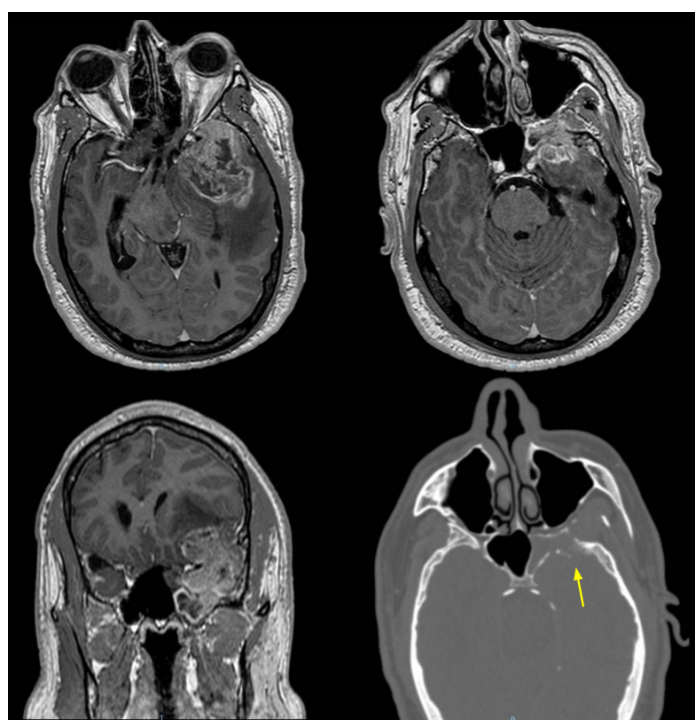

Figure 1 Initial admission T1 brain MRI with gadolinium enhancement shows a lesion centred at the left temporal lobe, measuring approximately 4.6 $\mathrm{cm} \times 3.7 \mathrm{~cm} \times 4.3 \mathrm{~cm}$ with peripheral enhancement and areas of necrosis at its most superior portion, causing a $1.1 \mathrm{~cm}$ left to right midline shift (axial-top row). There is a possible extension of the mass through the greater wing of the left sphenoid bone into the left sphenoid sinus (coronal-bottom row, left). The maxillofacial CT scan in the bone window (axial-bottom right) showed dehiscence of the posterior wall of the left sphenoid sinus (yellow arrow).

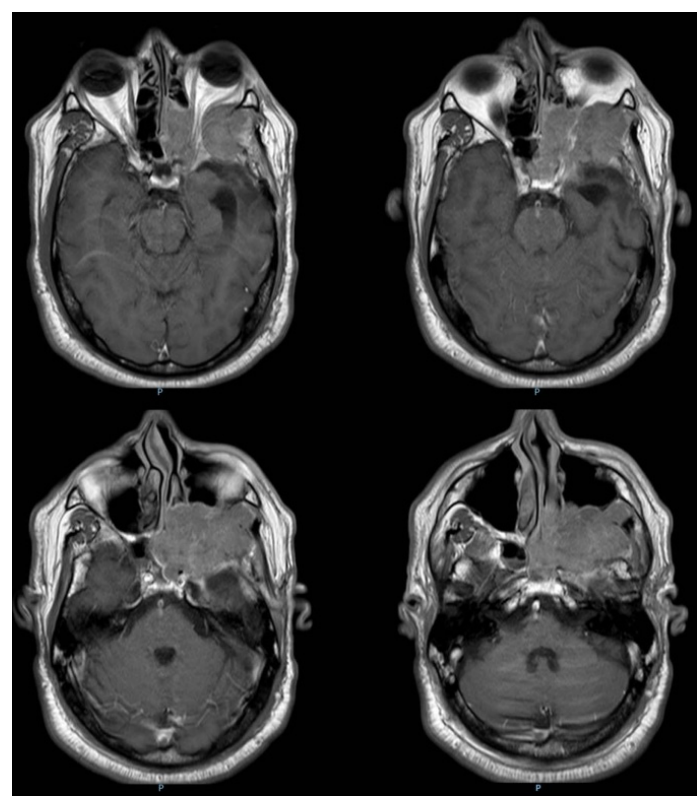

Figure 2 Second admission axial T1 brain MRI examination with gadolinium enhancement shows a large extra-axial mass centred within the left aspect of the sphenoid bone, measuring $7 \mathrm{~cm} \times 5.3 \mathrm{~cm} c \mathrm{c} \times 4.0 \mathrm{~cm}$. There is an extension into the left ethmoid, sphenoid and maxillary sinuses. There is also the involvement of the left orbital canal and orbital apex with extension to the left posterior nasal cavity and masticator space.

of adjuvant temozolomide therapy. The brain MRI performed 6 months after the radiotherapy showed no signs of disease recurrence.

Thirteen months after the first operation, he started reporting headaches. He had a Karnofsky score of 90. Neurological examination revealed an alert and oriented patient with left eye proptosis. Cranial nerve examination revealed hypoesthesia at the left trigeminal nerve maxillary division distribution. Extraocular movements were intact. The motor and sensory system examination disclosed no abnormality. Visual acuity at 6 feet was 20/25 on the right and 20/20 on the left. There was a left relative afferent pupillary defect and optic nerve swelling. The brain MRI showed a large extra-axial mass centred within the left aspect of the sphenoid bone with an extension into the left ethmoid, sphenoid and maxillary sinuses. The left orbital canal and orbital apex were also involved with extension to the left posterior nasal cavity and masticator space (figure 2). The anterior pole of the left superior temporal lobe and the left mesial temporal lobe showed small enhancing areas suggestive of recurrent intracranial disease. Intravenous chemotherapy was started, and he was alive at the last follow-up 
18 months after his initial diagnosis, still with a Karnofsky score of 90 .

Glioblastoma is a WHO grade IV aggressive and malignant brain tumour. Extracranial spread of the tumour is uncommon. ${ }^{12}$ The anterior and middle fossa floor provides an important route for the direct transdural extension of the tumour. ${ }^{2}$ Various hypotheses regarding extracranial spread had been proposed. The tumour can extend through a dural slit or can herniate through the dura due to increased intracranial pressure over a long time. ${ }^{2-4}$ Tumorous cells can infiltrate and destroy the dura. ${ }^{5}$ The tumour can also migrate across the dura mater through the cranial nerve foramina. ${ }^{67}$ All of these mechanisms may lead to an invasion of the skull base with infiltration of bones, neighbouring soft tissues, paranasal sinuses, orbit and infratemporal fossa. 189

\section{Learning points}

Glioblastoma is a tumour that can spread extracranially through the dura mater.

- Glioblastoma can invade and destroy the skull base and grow at the neighbouring soft tissues, paranasal sinuses, orbit and infratemporal fossa.

Contributors RJF-dT, JEPC, CMCC, ODJ were all responsible for the design, writing and approval of the manuscript.
Funding The authors have not declared a specific grant for this research from any funding agency in the public, commercial or not-for-profit sectors.

Competing interests None declared.

Patient consent for publication Obtained.

Provenance and peer review Not commissioned; externally peer reviewed.

\section{ORCID iD}

Ricardo J Fernández-de Thomas http://orcid.org/0000-0002-5210-8748

\section{REFERENCES}

1 Slowik F, Balogh I. Extracranial spreading of glioblastoma multiforme. Zentralb/ Neurochir 1980;41:57-68.

2 Liwnicz BH, Rubinstein LJ. The pathways of extraneural spread in metastasizing gliomas: a report of three cases and critical review of the literature. Hum Pathol 1979;10:453-67.

3 Erdem A, Tun K, Ugur HC, et al. Infratemporal and intraorbital metastasis of the glioblastoma multiforme. A case report. Neurochirurgie 2004;50:101-4.

4 Pompili A, Calvosa F, Caroli F, et al. The transdural extension of gliomas. J Neurooncol 1993;15:67-74

5 Tomac D, Chudy D, Lambaša S, et al. Extracranial propagation of glioblastoma with extension to pterygomaxillar fossa. World I Surg Oncol 2011;9:53.

6 Imataka S, Akiyama Y, Yokoyama R, et al. Transdural propagation of glioblastoma through foramen rotundum. World Neurosurg 2018;111:240-2.

7 Kwak R, Shatzkes D. Transdural spread of glioblastoma through the foramen ovale with presentation as a masticator space mass. AJNR Am J Neuroradiol 2009;30:808-10.

8 Shenoy SN, Raja A. Spontaneous transdural spread of glioblastoma with atypical presentation. Br J Neurosurg 2005; 19:61-5.

9 Rainov NG, Holzhausen $\mathrm{HJ}$, Meyer $\mathrm{H}$, et al. Local invasivity of glioblastoma multiforme with destruction of skull bone. Case report and review of the literature. Neurosurg Rev $1996 ; 19: 183-8$

Copyright 2021 BMJ Publishing Group. All rights reserved. For permission to reuse any of this content visit https://www.bmj.com/company/products-services/rights-and-licensing/permissions/

BMJ Case Report Fellows may re-use this article for personal use and teaching without any further permission.

Become a Fellow of BMJ Case Reports today and you can:

- Submit as many cases as you like

- Enjoy fast sympathetic peer review and rapid publication of accepted articles

- Access all the published articles

- Re-use any of the published material for personal use and teaching without further permission

\section{Customer Service}

If you have any further queries about your subscription, please contact our customer services team on +44 (0) 2071111105 or via email at support@bmj.com.

Visit casereports.bmj.com for more articles like this and to become a Fellow 